https://doi.org/10.52058/2786-4952-2022-2(7)-721-729

Чернишова Анна Михайлівна кандидат педагогічних наук, доцент кафедри мистецької освіти, Житомирський державний університет імені Івана Франка, вул. Велика Бердичівська, 40, м. Житомир, 10008, тел.: (067)729-87-55, https://orcid.org/0000-0003-4285-0022

\title{
ВИКОРИСТАННЯ УКРАЇНСЬКОГО ДИТЯЧОГО МУЗИЧНОГО ФОЛЬКЛОРУ ЯК ЕФЕКТИВНА УМОВА ЕСТЕТИЧНОГО ВИХОВАННЯ МОЛОДШИХ ШКОЛЯРІВ
}

Анотація. У статті актуалізовано проблему використання українського дитячого музичного фольклору як ефективної умови естетичного виховання молодших школярів. Встановлено, що органічною частиною духовної культури народу є музична культура людини. 3'ясовано, що в контексті національної культури існує багато невизначених аспектів проблеми музично-естетичного розвитку особистості. Сформульовано основну мету статті - з'ясувати шляхи підвищення ефективності розвитку музично-естетичної культури дітей початкової ланки освіти.

Проведений аналіз наукових праць 3 досліджуваної проблеми свідчить: музика більше, ніж будь-який інший вид мистецтва, впливає на формування ідейних і морально-етичних почуттів, національної самосвідомості, виховання всебічно розвиненої особистості, засвоєння історії та культури свого народу. Педагогічна практика давно цікавилась питаннями впливу народної творчості на виховання дітей, значне місце в якій належить музичному фольклору. Українська народна пісня вважається справжнім золотим фондом української музичної культури. Для формування естетичного ставлення дітей до української народної музики необхідно спрогнозувати їх загальний рівень естетичного розвитку та виявити естетичні потреби та інтереси, властиві школярам цього віку.

3'ясовано, що молодший шкільний вік $є$ важливим періодом для оволодіння національною культурою, накопичення знань та формування людських цінностей у конкретному середовищі. Проведений аналіз шкільних програми з музики для 1-4 класів свідчить: народна пісня відіграє важливу роль у навчанні, а головне завдання вчителя - допомогти дітям зрозуміти іï музичнопоетичну гармонію. Програма з музики для учнів початкової школи побудована на творах дитячого фольклору та календарно-обрядової тематики.

Визначено, що особливої уваги потребує не сам музичний твір, а викликані його сприйняттям настрої, почуття, думки дітей. Значний вплив на музичноестетичний розвиток учнів матиме їхня участь у позакласній діяльності, де для фольклору більш широкий простір. Констатовано, що використання 
українського пісенного фольклору в навчально-виховній роботі підвищує ефективність розвитку музично-естетичної культури дітей початкової ланки освіти.

Ключові слова: дитячий музичний фольклор, естетичне виховання, культура, молодші школярі, народна музична творчість, українська народна пісня.

Chernyshova Anna Mykhailivna Candidate of Pedagogical Sciences, Associate Professor of the Department of Art Education, Zhytomyr Ivan Franko State UniversityVelyka Berdychivska St., 40, , Zhytomyr, 10008, tel.: (067)729-87-55, https://orcid.org/0000-0003-4285-0022

\section{THE USE OF UKRAINIAN CHILDREN'S MUSICAL FOLKLORE AS AN EFFECTIVE CONDITION FOR AESTHETIC EDUCATION OF PRIMARY SCHOOL CHILDREN}

Abstract. The article actualizes the problem of using Ukrainian children's musical folklore as an effective condition of aesthetic education of junior schoolchildren. It is established that human musical culture is an organic part of the spiritual culture of the people. It was found that there are many uncertain aspects of the problem of musical and aesthetic development of the individual in the context of national culture. The main purpose of the article is to find out ways to increase the effectiveness of the development of musical and aesthetic culture of children in primary education. The analysis of scientific works on the researched problem shows that music, more than any other kind of art, influences the formation of ideological, moral and ethical feelings, national self-consciousness, education of a fully developed personality, assimilation of history and culture of its people. Pedagogical practice has been interested in the influence of folk art on the upbringing of children for a long time, where a significant part belongs to musical folklore. Ukrainian folk song is considered to be a real golden fund of Ukrainian musical culture. To cultivate an aesthetic attitude to Ukrainian folk music it is necessary for children to anticipate the level of their general aesthetic development, to identify the aesthetic needs and interests inherent for schoolchildren of this age. It was found that the early school age is an important period for mastering the culture of their people, the accumulation of knowledge, the formation of human values in a particular environment. The analysis of school music programmes for grades 1-4 shows that a significant place in learning is given to folk songs and the main task of the teacher is to help the child understand its musical and poetic harmony. The music programme for primary school students is based on children's folklore and works that cover calendar and ritual themes. It is considered that the subject of attention should be not the musical work itself but the mood, feelings, thoughts of children, caused by its perception. Their participation in extracurricular activities, where there is a wider area for folklore, will have a significant impact on the musical and aesthetic development of students. It is stated 
that the use of Ukrainian song folklore in educational work increases the effectiveness of the development of musical and aesthetic culture of primary schoolchildren.

Keywords: aesthetic education, children's musical folklore, culture, folk music, junior schoolchildren, Ukrainian folk song.

Постановка проблеми. Зміни, що відбуваються в соціально-економічній, політичній та культурній сферах України, актуалізують проблему всебічного гармонійного розвитку дитини. У iї вирішенні суттєве місце належить питанням, пов'язаним із залученням підростаючого покоління до естетичного досвіду людства, освоєння й використання естетичних цінностей, активної художньо-творчої діяльності. Саме тому важливого значення набуває процес естетичного виховання дітей і молоді.

У Національній доктрині розвитку освіти України у XXI столітті, у Державній комплексній програмі естетичного виховання зазначається, що саме в системі освіти цілеспрямовано, послідовно й ефективно здійснюється естетичне виховання дитини, яка здатна сприймати, розуміти та використовувати художньо-естетичні цінності в житті та мистецтві [1]. Тож сучасна школа спрямовує свої зусилля на те, щоб забезпечити належним чином процес естетичного виховання учнівської молоді, створити педагогічні умови, які б сприяли підвищенню рівня її естетичної вихованості. Важливим засобом реалізації поставленого завдання є залучення підростаючого покоління до народнопісенної творчості.

Аналіз останніх досліджень і публікацій. Відомі філософи та історики у своїх працях зосереджували свою увагу на використанні фольклорних творів у вихованні підростаючого покоління (М. Аркаса, М. Грушевського, М. Костомарова, І. Огієнка, О. Субтельного та ін.). Вони зазначали, що народна мудрість $€$ матеріалом для творчого прояву, навчання та виховання, а безпосереднє залучення у фольклор активізує здатність особистості до здобуття знань, розширює спектр емоцій та почуттів.

У ряді наукових праць (К. Абишева, А. Анаркулової, О. Апраксіної, В. Бабія, А. Владимирової, Р. Дзвінкої, Ю. Мандрика, Н. Сивачук, В. Стрельчук, В. Шацької та ін.) народна музична творчість розглядається як система музично-естетичного виховання й розвитку творчих здібностей учнів.

Естетико-соціологічні та музикознавчі узагальнення щодо розкриття художніх цінностей української народної музики здійснені сучасними педагогами у своїх наукових дослідженнях (Н. Костюк, Л. Корній, І. Ляшенко, Т. Мартинюк, В. Шульгіна та ін.).

В естетичному вихованні особистості велику роль відіграє народна музика, про що свідчать численні праці науковців та думки вчителів-практиків. У своїй роботі вони намагаються донести красу та чарівність народної музики до дитячих сердець. Проте й наразі існують невизначені аспекти проблеми музично-естетичного розвитку особистості в контексті національної культури. 
Журнал«Герспективитаінновації наукиљ

(Серія«Гедагогіка», Серія«Гцихологія», Серія«Медицинв»

№2(7) 2022

Мета статті - з'ясувати шляхи підвищення ефективності розвитку музично-естетичної культури дітей початкової ланки освіти.

Виклад основного матеріалу. Сучасні учені (А. Арнольдов, Ю. Афанасьєв, Е. Бадлер, О. Боголюбов，В.Давидович， Д. Джола， А. Жданов， В. Зінченко, М. Злобін, І. Зязюн, М. Каган, М. Кисельов, О. Толстих та ін.) у своїх роботах пропонують різні підходи до тлумачення поняття «культура». Культура як кінцевий продукт діяльності людей розглядається цілим рядом дослідників; інші вкладають в це поняття сукупність особистісних якостей людини; треті пояснюють це поняття через діяльність, у процесі якої людина здатна розкрити цілісність та універсальність своєї внутрішньої сутності.

Одним із найважливіших аспектів багатого культурного розвитку слугує народна музика, яка охоплює мистецькі здобутки багатьох поколінь, художній досвід маловідомих народних співаків та інструменталістів. Фольклорний здобуток народу є проявом пережитого болю та радощів минулого, вияву добра і зла, віри та чесності, впевненості у щасливому майбутньому.

Фольклор - це художне відображення дійсності у словесних, музичнохореографічних, драматичних формах колективної народної творчості, пов'язаної з життям і побутом, світобаченням суспільства. Фольклор відображає національну психологію та свідомість народу, його історію та досвід, філософію та мораль, етичні та естетичні ідеали. Щоб пізнати минуле, сучасне та майбутнє нашого народу, необхідно вивчити народний фольклор [2, с. 46].

Питаннями впливу народної творчості на розвиток підростаючого покоління здавна цікавилась педагогічна практика. Український фольклор як засіб педагогічного впливу на учнів високо оцінював В. Сухомлинський. «Яким невичерпним матеріалом $\epsilon$ народна творчість для розвитку, найвитонченішого розвитку найблагородніших i найважливіших почуттів у серці молодого покоління!» [3].

Найпростішим і найпоширенішим видом вокальної музики є пісня. У ній присутнє поєднання поетичного та музичного образів. Характерними ознаками пісні є присутність цілісної, самостійної, красивої та простої за будовою мелодії, музика повністю відповідає загальному змісту тексту [4, с. 30].

Народна пісня $\epsilon$ душею народу, його історією. Пісенність українського народу формувалась та примножувалась століттями, саме тому вважається справжнім золотим фондом української музичної культури. Народна пісня - це мова народу, його історія, національне багатство й культура. Вона супроводжує людину усе життя, прикрашає його та допомагає у роботі.

Музично-естетична культура учнів початкових класів засобами пісенного фольклору формується у процесі пізнання народних художніх цінностей та виявленні здатності до творчого розвитку. Це є свідченням рівня естетичного розвитку особистості та їі проявів в різноманітній діяльності у сфері певного виду мистецтва.

У процесі формування естетичного ставлення дітей до української народної музики необхідно спрогнозувати їх загальний рівень естетичного розвитку та 
виявити естетичні потреби та інтереси, властиві учням цього віку. «У житті людини $\epsilon$ оптимальні періоди, коли вона може 3 найкращим результатом оволодіти певним обсягом знань, засвоювати вміння й навички, розкривати свої здібності» [5, с. 23]. У будь-якому навчальному процесі, особливо у вихованні у молодшої учнівської молоді естетичного ставлення до української народної музики, необхідно виявити ці «оптимальні періоди» [6].

Через залучення учнів початкової ланки до музичної спадщини рідного народу збагачується їх емоційний досвід (спектр почуттів та вміння їх переживати). Естетичне ставлення до української народної музики сприяє розвитку в учнів творчого ставлення до дійсності, дає можливість виявити їх нахили та здібності. Це полегшує дитині шлях входження у новий світ, в якому вона може знайти й розкрити себе [7, с. 59].

Особливо сприятливими до педагогічного впливу $\epsilon$ учні молодшого шкільного віку, їхні художні смаки незрілі та тільки формуються. Тому дуже важливо використати цей сенситивний період для формування їх музичноестетичної культури. Слухання і виконання народних пісень з раннього віку сприяє поступовому засвоєнню їх мелодії та ритмічних особливостей, запам’ятовуванню тексту, вони стають знайомі та близькі.

Духовним початком людського життя є любов до народної музики та пісні, адже кожна дитина генетично народжується із зачатками музичної свідомості, яка в далекому минулому стала могутнім елементом музичного фольклору. Наголошуючи на важливості фольклору у процесі формування особистості писав В. Сухомлинський: «Мелодія і слово рідної пісні - це могутня виховна сила, яка розкриває перед дитиною народні ідеали і надії» [3].

Одним із найважливіших джерел розвитку дітей є народна пісня. Тому велике значення у вихованні молодших школярів має відродження народнопісенної культури. Слова та вирази народних пісень повинні змалку увійти у дитячі серця, щоб запалити іскру доброти і справедливості. Велика увага народній пісні приділяється українськими композиторами та педагогами, оскільки це найдемократичніший жанр, який близький і зрозумілий дітям.

Про органічний зв’язок музичної культури людини з культурою народу, до якого вона належить або серед якого живе, зазначено у авторських програмах 3 музичного мистецтва для загальноосвітніх шкіл учнів 1-4 класів (О. Ростовський, О. Марченко, Л. Хлєбнікова, 3. Бервецький).

В основу усіх програм з музики для учнів початкових класів покладено саме дитячий фольклор. Він включає в себе безпосередньо дитячу творчість (скоромовки, лічилки), словесну творчість дорослих для дітей (колискові пісні, забавлянки, пестушки та ін.), творчість дорослих, яка 3 часом перейшла до дитячого репертуару (ігрові пісні). Таким чином, народній пісні у програмі відведено значне місце. Тому саме учителю відведена головна роль: допомогти дитині усвідомити музично-поетичну гармонію народної пісні.

Календарно-обрядові пісні, у яких відображено образи і явища природи, мають велику художню цінність. Вивчаючи на уроках музики обрядові пісні, 
пов'язані з календарними датами, учитель знайомить учнів із піснями зимового, весняного та літньо-осіннього циклу. Для вивчення пропонуються такі твори як: купальські та жниварські пісні, веснянки, колядки і щедрівки («Вийди, вийди, сонечко», «Подоляночка, «Ми кривого танцю йдемо», «Вийди, вийди, Іванку», «Щедрівочка щедрувала», «Коляд, коляд, колядниця», «Вийшли в поле косарі», «Кругом, женчики, кругом», «А вже весна» та інші [5, с. 22-23].

У процесі знайомства 3 народним календарем діти вивчають ігровий фольклор: колядки, щедрівки, пісні про святого Миколая, веснянки, гаївки, зажинкові, жниварські, обжинкові пісні, дитячі лічилки, українські народні пісні 3 елементами гри. Ігрова діяльність на уроці музики стимулює уяву учнів, розвиває фантазію, задовольняє їх потребу у спілкуванні та допомагає набути певний соціальний досвід.

3 народний пісень («Зацвіла в долині», «Вербовая дощечка», «Калинова пісня», «Ой єсть в лісі калина», «Калинова сопілка», «Ой вербо, вербо» та ін.) діти дізнаються про українську національну символіку (калину, вербу, тополю, барвінок), що позначиться на їх патріотичному вихованні та формуванні правильного ставленні до живої природи [7, с. 59-60].

Для учнів початкових класів велике значення має розуміння давніх календарних обрядів у контексті духовно-культурного виховання. Відображення найкращих рис українського народу у фольклорних образах, ідеях, символах, пробуджують національну самосвідомість та формують патріотичні почуття у підростаючого покоління.

Колискові пісні займають особливе місце у пропонованому репертуарі. Їх сюжети досить прості, зрозумілі та переносять дітей у світ глибокої материнської любові. Саме колискові пісні знайомлять дитину із мовою та звуком, навчають розуміти значення слів як звукосполучень. Співаючи колискову своїй дитині, мати передає їй усю доброту, душевний спокій та красу своєї мови. Діти, які змалку слухали колискові пісні, значно краще розвиваються емоційно, розумово та морально [8, с. 61].

Учням четвертих класів пропонуються для вивчення нові жанри української пісні такі як: думи, історичні пісні, коломийки та жартівливі пісні, які доповнюють отримані знання учнів та розширюють їх уявлення щодо розмаїття українського музичного фольклору («Ой попід гай зелененький», «Гей, там на горі Січ іде», «Маруся Богуславка», «Іван Богун» та ін.) [4, с. 31].

Перш ніж прослухати та розучити народну пісню, педагог має розповісти коротку історію їі виникнення у цікавій та зворушливій формі, врахувавши індивідуальні особливості учнів. Також дієвою формою роботи є бесіда, яка здатна викликати у дітей інтерес до народної пісні, сприяти глибокому розумінню змісту твору, кращому сприйняттю його особливостей та художнього значення пісенного фольклору. Педагог має розкрити значення фольклору у формуванні співочої культури, використовуючи розповідь-бесіду, адже у народній пісні ритм музики підпорядковується ритму й мелодії словесних текстів [5, с. 23]. 
Необхідно звернути увагу школярів й на притаманні багатьом українським народним пісням поетичні паралелізми («Та продай, бабусю, бичка», «Вербовая дощечка», «Вгору, сонінко», «Соловеєчку, сватку, сватку», «А ми просо сіяли», «Зайчику, зайчику», «Ягілочка»); метафори («Вийди, вийди сонечко», «Ой на горі жито», «Ой вербо, вербо», «Ой ходить сон», «Вийди, вийди, Іванку»); образи («Ой сивая та і зозуленька», «Грицю, Грицю, до роботи», «Дівка Явдошка») та символи («Ой минула вже зима», «Гей там на горі січ іде», «Се наша хата»). Так у пісні «Вгору, сонінко» використані поетичні паралелізми: дивувалися ліси, де ся поділи вівси. Женчики позжинали залізними серпали. Залізними серпами, біленькими руками; у пісні «Зайчику, зайчику» - поетичні паралелізми: зайчику, зайчику, мій братчику! Не скачи, не скачи по городчику. У пісні «Ой ходить сон» виокремлюємо метафори - ой ходить сон коло вікон; питається сон дрімоти. У пісні «Ой минула вже зима» - прилетіли журавлі - це символ весни; у пісні «Се наша хата» - Трійия, Спаситель і Божа Мати - релігійні символи; у пісні «Ой єсть в лісі калина» - калина - символ України [4, с. 32].

Варто зосередити увагу школярів й на морально-естетичному змісті тексту і музики, на емоційному та моральному ставленні людей до дійсності. Слід підкреслити значення слова і музики, які доповнюють одне одного у створенні єдиного художнього образу та відповідного настрою.

Особливої уваги потребує не сам музичний твір, а викликані його сприйняттям настрої, почуття, думки дітей. Важлива роль учителя на цьому етапі полягає у спостереженні за учнями та намаганні зрозуміти їхні емоції, думки та почуття. Деякі учні емоційно сприймають музику, змінюючи вираз свого обличчя, а частина - наспівує мелодію, поєднуючи ії з рухами. Цікавим завданням на уроках музики, на наш погляд, є малювання сюжету на основі почутих мелодій. Такий практичний метод допоможе зосередити увагу учнів на мелодії, емоціях та почуттях, викликаних нею, та розвивати уяву і фантазію [5, с. 22].

Значний вплив на музично-естетичний розвиток учнів має залучення їх до позакласних заходів, організованих учителем музики. Саме у такій діяльності відкриваються більші можливості для фольклору: учні можуть відвідувати музичні гуртки, музичні концерти і потім їх обговорювати разом з учителем, приймати участь у шкільних святах, де виконуються народні пісні, та бути учасником українського фольклорного ансамблю.

Самодіяльність та організованість у єдності забезпечують ефективність цих форм у залученні дітей до народної пісні та фольклору. Розучуючи 3 дітьми українську народну пісню, вчитель має дотримуватись певної методики, яка грунтується на організаційно-педагогічних вимогах, розумінні вчителем i батьками необхідності ознайомлення учнів з українськими народними творами, залученні вчителів до практичних робіт, спрямованих на формування в учнів знань про пісенну творчість їхньої місцевості. Важлива роль у цьому належить саме учителю музики та його творчому вирішенню проблеми. Він повинен уміти аналізувати народну музику, підбирати оптимальний дидактичний матеріал як для навчальний занять, так і для виховних заходів, враховуючи індивідульні особливості дітей [4, с. 31]. 
Журнал«Герспективитаінноваціїнауки»

(Серія «Гедагогіка», Серія«ГТихологія», Серія«Медицине»

№2(7) 2022

Для виховання духовності дитини вчитель має допомагати їй орієнтуватися у світі музики та підбирати високохудожні твори, що сприяють розвитку емоційної культури, музичного та естетичного смаку учнів. Добре продумана навчальна діяльність та фольклорно-виховні заходи, де звучить народна пісня, сприятиме вихованню в учнів початкових класів любові до музичного мистецтва, формуванню у них музично-естетичної культури та збагаченню духовності.

Висновки. Підсумовуючи, можна сказати, що ефективним шляхом розвитку музично-естетичної культури молодших школярів $\epsilon$ використання у навчально-виховній роботі українського пісенного фольклору як матеріалу для керівництва їх музично-естетичною діяльністю. Насиченість шкільної програми фольклором сприяє наближенню учнів до уявлень про людську природу, красу й гармонію навколишнього світу, вироблені століттями. Залучення учнів початкових класів до української народнопісенної творчості створить усі необхідні умови для повноцінного розкриття їх особистісних здібностей, естетичного виховання, відродження та популяризації народнопісенної культури. Виконане дослідження не вичерпує всіх аспектів актуалізованої проблеми. Подальшого вивчення потребують питання, пов'язані $з$ пошуком і апробацією нових форм та методів естетичного виховання молодших школярів засобами музичного мистецтва.

\section{Jimepamypa:}

1. Національна доктрина розвитку освіти України у XXI столітті. К.: Шкільний світ, 2001.

2. Горобець Н. Формування естетичних почуттів у молодших школярів. Рідна школа. 2013. №11. C. 46-49.

3. Сухомлинський В. О. Вибрані твори: в 5 т. К.: «Рад. школа», 1977. Т.5 . 1977. 639 с.

4. Печерська $Є$. П. Інтегрований вплив музики і природи на естетичне виховання. Почактова школа. 2011. №7. С. 29-32.

5. Фоломєєва Н. Алгоритми авторської технології естетичного виховання дітей засобами музики. Рідна школа. 2012. №6. С. 21-23.

6. Виготський Л. С. Психологія мистецтва. М.: Просвіта, 1986. 180 с.

7. Барвінок I. В. Визначення рівня розвитку музично-естетичної культури у школярів. Рідна школа. 2013. №5. С. 59-61.

8. Субота М. В. Сприймання школярами музичного твору. Практична психологія та соиіальна робота. 2011. №1. С. 58-62.

\section{References:}

1. Natsionalna doktryna rozvytku osvity Ukrainy u XXI stolitti [National doctrine of education development of Ukraine in the XXI century]. (2001). K.: Shkilnyi svit [in Ukrainian].

2. Gorobets N. (2013). Formuvannia estetychnykh pochuttiv u molodshykh shkoliariv [Formation of aesthetic feelings in junior high school students]. Ridna shkola - Native school, 11, 46-49 [in Ukrainian].

3. Sukhomlynskyi V. O. (1977). Vybrani tvory: v 5 t. [Selected works in 5 volumes]. Kyiv: Rad. Shkola [in Ukrainian].

4. Pecherska Ie. P. (2011). Intehrovanyi vplyv muzyky i pryrody na estetychne vykhovannia. [Integrated influence of music and nature on aesthetic education]. Pochaktova shkola - Primary School, 7, 29-32 [in Ukrainian]. 
5. Folomieieva N. (2012). Alhorytmy avtorskoi tekhnolohii estetychnoho vykhovannia ditei zasobamy muzyky. [Algorithms of author's technology of aesthetic education of children by means of music]. Ridna shkola - Native school, 6, 21-23 [in Ukrainian].

6. Vyhotskyi L. S. (1986). Psykholohiia mystetstva. [Psychology of art]. M.: Prosvita [in Ukrainian].

7. Barvinok I. V. (2013). Vyznachennia rivnia rozvytku muzychno-estetychnoi kultury u shkoliariv. [Determining the level of development of musical and aesthetic culture in schoolchildren]. Ridna shkola - Native school, 5, 59-61 [in Ukrainian].

8. Subota M. V. (2011). Spryimannia shkoliaramy muzychnoho tvoru. [Students' perception of a piece of music]. Praktychna psykholohiia ta sotsialna robota - Practical Psychology and Social Work, 1, 58-62 [in Ukrainian]. 